\title{
Teopoëtika (radikale Godstaal) en I.L. de Villiers se gedigte
}

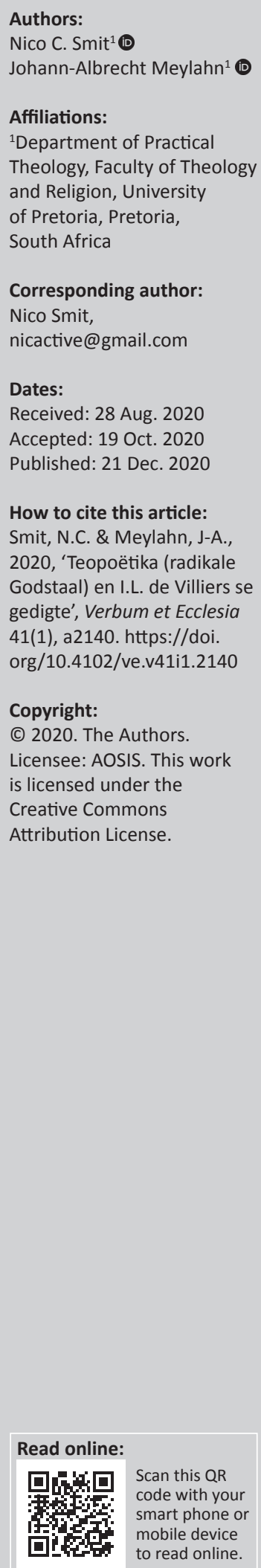

\begin{abstract}
Theopoetics (radical God-talk) and the poems of I.L. de Villiers. Is a postmodern God-talk possible and can poetry be used to execute the question? The article focuses on whether the term theopoetics can be applied to the works of De Villiers and whether they are only theopoetry. The building blocks (the terms from which theopoetics originates) of theopoetics are explained. This entails poetic analysis, metaphor and all the forms of metaphor, narrative theology, postmodern philosophy (and postmodernity), social construct and narrative, imagination, people's search for aesthetics (also literary aesthetics), as well as mysticism. One of the main questions in this article points to the possibility that theopoetics (radical postmodern God-talk) can be a mode of speech after the death of God and whether it provides a way to talk about God when metaphysics cannot speak of God anymore. Poetry and theopoetics are compared and a way is shown of how poetry can assist to speak about God. Meylahn's proposed method was chosen to execute the research. Two poems that are to be read theopoetically are also presented in this article.

Intradisciplinary and/or interdisciplinary implications: The article explores the possibility of postmodern God-talk within Practical Theology. The traditional discourses and/or views of metaphysics are being challenged through exploring the possibility of theopoetics and its contribution to postmetaphysical God-talk as a third - or middle - way to speak of God.
\end{abstract}

Keywords: postmodern God-talk; I.L. de Villiers; poetry; theopoetics; postmodernism; radical theology; liturgy.

\section{Inleiding}

Die woorde teopoësie en teopoëtika (teopoëties) is al heelwat deurdink en geformuleer in ander tale en kerke. Daar is selfs universiteite wat die vak Theopoetics doseer, maar binne die Nederduitse Gereformeerde (NG) Kerk en liturgiewetenskap in 'n Suid-Afrikaanse konteks, en veral in Afrikaans, is daar nog relatief min in hierdie veld gedoen en nagevors.

Die woorde 'teopoëtika' en 'teopoëties' (teopoetics) dien as sinonieme in hierdie artikel, maar die woord teopoësie (theopoetry) het wel 'n ander betekenis. Die Handwoordeboek van die Afrikaanse Taal (2015) beskryf nie die woorde 'poësie' en 'poëties' as sinonieme nie. Poësie beteken gedigte, verse, die kuns van gedigte skryf en digterlike bekoring, terwyl poëties as digterlik verstaan kan word. Dit is egter belangrik om kennis te neem dat daar in hierdie artikel 'n verskil in die betekenis tussen teopoëties en teopoësie is. In dié navorsing beteken teopoësie die mooiheid en moontlikheid daarvan om teologiese waarhede op ander maniere uit te druk, terwyl teopoëtika 'n ander betekenis het. Die onderskeid in terme dui aan dat Afrikaans ook taalsosiologies aanpas by 'n meer moderne leksikon en daarom word die woord theopoetics vertaal as 'teopoëtika', terwyl theopoetry as 'teopoësie' vertaal kan word. In hierdie artikel word daar op teopoëtika gefokus.

Teopoëtika is 'n interdissiplinêre veld, verrykend tot die teologie, wat verskeie elemente en idees saamvoeg, soos prosesteologie, narratiewe teologie en postmoderne filosofie. In teopoëtika gaan dit grootliks oor teologiese en religieuse verbeelding. Teopoëtika neem die gestalte aan om (eerder) voordat daar 'n 'wetenskaplike' teorie oor God ontwikkel word - soos sistematiese teologie poog om te doen - mense in staat te stel om God te vind deur poëtiese artikulasie en geleefde (deurleefde) ervarings.

Die frase 'after the death of God' is bepalend in teopoëtika. Die term is veral deur die Duitse filosoof Friedrich Nietzsche gebruik. Nietzsche se gelykenis vertel van die mal man (madman) wat rondhardloop en aankondig: 'God is dood' (Gott ist tot). Die beskrywing 'dood van God' beteken nie dat God letterlik dood is nie, maar dien as verwysing na die afsluiting van die moderne fase. 
Die woorde 'God is dood' verwys daarna dat die Verligting 'n einde gebring het aan die moontlikheid van God se bestaan. Die moderne era het ongeveer in die 1930's tot' $n$ einde gekom, gevolg deur die postmodernisme. Dit is in 1966 dat TIME Magazine die woorde in rooi publiseer: 'Is God dead?' Teopoëtika ontwikkel dan vanuit die 'God is dood'-beweging.

Die vraag waarop hierdie artikel lig wil werp is: Kan I.L. de Villiers se poësie as teopoëtika beskryf word? Ten einde die vraag te verken, sal daar uitgebrei word oor wat teopoëtika binne 'n Afrikaanse konteks kan beteken en ook teopoëtika se ontwikkeling aantoon vanaf die 1960's en hoe 'n radikale Godstaal kan lyk. Dis die vrae waaraan die artikel aandag wil skenk.

\section{Wat is teopoëtika (theopoetics en /of radikale Godstaal)?}

Teopoëtika is radikale Godstaal. Dit is om oor God te praat sonder metafisika, selfs al word metafisiese taal gebruik of aangewend. Dit is die wegbeweeg van die metafisika af, maar nie om die metafisika bloot af te wys nie, soos Heidegger ([1971] 1996) dit beskryf in sy boek Being and time nie. Dit wil uitwys dat daar nie net een konkrete manier is om oor God te praat nie - soos wat die moderne era beklemtoon het nie - en dat daar ook nie een enkele interpretasie van God is nie, maar dat daar veel meer interpretasies van God kan wees. Metafisika word eerder in hierdie taal geïnkorporeer, sodat postmoderne Godstaal moontlik is.

Die term teopoëtika (theopoetics) is die eerste keer gebruik as die woord 'theopoiesis' deur Stanley Romaine Hopper in 'n toespraak in 1971 wat uit voorafgaande gesprekke gespruit het wat in die American Academy of Religion plaasgevind het. Sedertdien dien teopoëtika as 'n naamwoord wat na 'n bepaalde kwaliteit verwys, hetsy die toewydingskwaliteit van 'n teks, die genre van godsdienstige skryfwerk of 'n postmoderne perspektief op teologie. Hopper (1992:225) meen dat die pad vorentoe individue sal lei in 'n nuwe taal waar teologie nie rigied is nie, nie net bestaan uit logiese bewerings nie, maar ook uit vreugdevolle ekstatiese uitdrukkings wat geskep word, 'n teologie wat nie 'teo-logies' nie, maar 'teo-poëties' is. Teopoëtika beklemtoon die poësie en die wese van die mens in hulle 'huis van taal'. 'Huis van taal' word veral deur Heidegger (1977:217-218) gebruik en hy meen dat elke mens in ' $n$ 'huis van taal' woon. Heidegger (1977:218) beskryf dit as volg: 'Language is the house of Being. In its home man dwells. Those who think and those who create with words are the guardians of this home.' Dus dra teopoëtika daartoe by om die huis te skep.

Die vraag is dan: Wat wil teopoëtika vir die mens in 'n postmoderne tyd vertel? Teopoëtika kan kortliks beskryf word as 'n moontlike strategie wat vir die mens betekenis kan gee in die afwesigheid van vaste en ware betekenisse in die kennis van geloof. Dit beteken om die individu te help om God te kan verwoord in ' $n$ tyd waarin daar nie een bepaalde waarheid oor God is nie, by name 'n postmoderne wêreldbeeld. Teopoëtika is ook deeglik bewus van die metaforiese karakter (Miller 2010:10) van taal. Heidegger (1996:104) verduidelik dat taal die mag het om 'n wêreld te skep. Heidegger (1996:104) vra vrae soos: 'What are words, that they have the power to endow things with Being?' En dan ook: 'What are things that they need words in order to be?' Meylahn (2012a) beskryf dan die wese van teopoëtika as volg:

Theopoetics consciously engages the bringing forth out of nothing ... [it] faces the radical crisis of faith and therefore requires a radicalised poetics to face the nothingness, the void, the absolute alterity. (bl. 7)

Met die bostaande stelling in ag geneem, is daar ruimte en plek vir 'n radikale Godstaal wat as teopoëtika beskryf word. Teopoëtika wys ook die moontlikhede uit vir 'n postmetafisiese Godstaal wat vir die mens wat soekend is aanvaarbaar kan wees. Teopoëtika bestaan uit 'n aantal konsepte. Dit sal vir die doel van hierdie artikel net kortliks bespreek word.

'n Persoon wat nie die term 'teopoëtika' ken of enigiets daarvan af weet nie, sou dit dalk kon beskryf as 'n hibried tussen poësie en teologie, maar teopoëtika is meer as net dit - dit is ' $n$ totaal ander manier om te dink oor die lewe en hoe die lewe beleef kan word. Dit is om te skep uit die niks uit nie (ex nihilo); dit skep ook ruimte.

\section{Teopoëtika is 'n skeppingsproses}

In teopoëtika word aangevoer dat alles wat geskryf word hetsy 'n poëtiese genre, 'n verhaal in die narratiewe vorm of selfs 'n teoretiese dokument - 'poiesis' bly: 'n skeppingsproses.

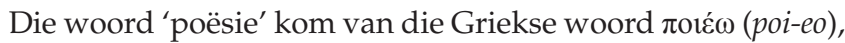
wat letterlik beteken 'om te maak'. Dit is 'n vindingryke, intuïtiewe en verbeeldingryke handeling wat uitgevoer word deur die skrywer; die skrywer is besig om te maak of om te skep. Die skrywer se vertelling roep ander vertellings na vore. Die metafoor wat die skrywer gebruik, moedig die leser aan om nuwe moontlike metafore te skep en te visualiseer. Dit moedig ook gesprekke aan (Holland 2007:317-331).

In die skeppingsproses kan teopoëtika dan die ruimte bied vir postmetafisiese taal oor God, nie om God in vaste en geformuleerde definisies vas te vang nie, maar ruimte te bied dat mense God deur hul ervaring kan beskryf. Teopoëtika skep die moontlikheid om oor God te praat wanneer die metafisika nie meer oor God kan praat nie.

\section{Teopoëtika is 'n derde weg en /of middeweg}

Teopoëtika is taal oor God wat ten volle bewus is van die beperkings van fisika, metafisika, filosofie en taal. Richard Kearney beskryf dié ontmoeting met God as 'n derde weg in sy boek Anatheism (2010).

Die derde weg is om God te ontmoet, selfs wanneer God homself verskuil of nie openbaar nie. Dit kan die aanroep van die veelvuldige name van God wees. Kearney (2001:7) beskryf hierdie belewing van God as 'God agter, verder agter'. Dit is die wegbeweeg van konkrete idees en 
tradisionele 'waarhede' oor God sodat daar ook ander benamings kan wees vir God en ander maniere om God te beskryf.

Teopoëtiek staan in kontras met teologiese 'style' wat losweg gedefinieer kan word as onto-teo-logika (onto-teologie in die taal van Heidegger en Hopper), waarin logika en rasionele denke gebruik word om die waarheid te soek. Teologie bied geen uitnodiging, misterie of dubbelsinnigheid in betekenis nie, terwyl teopoëtika wel die uitnodiging van ruimte en vryheid in godsdiens vir individue bied.

\section{Teopoëtika praat oor God na die 'dood van God'}

Teopoëtika praat oor God, want God is 'n naam waardig om te red, die moeite werd om lief te hê, 'n naam wat roep (Meylahn 2013:301). Teopoëtika is taal oor God ná die dood van God, die dood van die metafisiese onto-teologiese God. Binne teopoëtika word individue toegelaat om nuut en selfs binne nuwe taal oor God te kan praat. Dit is taal wat nie rigied is of vasgevang word in definisies en vaste uitdrukkings nie, maar wat ruimte maak en skep om uitdrukking aan die misterie te kan gee.

\section{Strominge in die 'God is dood'-beweging}

Daar is hoofsaaklik drie strominge binne die 'God is dood'-beweging. Die eerste is dié van Thomas J.J. Altizer (Altizer \& Hamilton 1966) se 'ekstreme kenosis', waarin hy meen dat God ten volle mens geword het in Christus en dat God alle almag verloor het in dié menswording. Die tweede stroming is dié van William Hamilton (Altizer \& Hamilton 1966), wat 'n sosiologiese diskoers aanvoer: die moderne mens kan nie meer in God glo nie en daarom kan die kerk ook sonder God klaarkom. Hamilton werk vanaf die uitgangspunt dat radikale teologie en die dood van God moontlike oplossings bied wanneer tekste uitgelê word. En dan is daar Paul van Buren (Frame 1988) se sosiologies linguistiese redevoering: '[T]he concept of God was "cognitively meaningless," since God's existence and nature were not verifiable or falsifiable by the methods of science' (Keefe-Perry 2014:23).

Keefe-Perry (2014:23) verwys na 'n hoofstuk deur John Frame met die titel Death of God theology in die boek deur Ferguson, Wright, Packer, (1988) New dictionary of theology waarin Frame (1988) die verskillende moontlikhede lys wat die dood van God kan beteken en die nodigheid en belang van postmoderne Godstaal:

- Daar is geen God nie en daar was nog nooit nie.

- Daar was eens 'n God wat geloof en geprys is, maar nou is daar nie meer so 'n God nie.

- Die idee van God en die woord God het radikale herformulering nodig.

- Ons tradisionele liturgiese en teologiese taal het ' $n$ totale nuwe dimensie (overhaul) nodig.

- Die Christelike storie is nie meer een wat genees of red nie. Dit is nou net vir instruksie of leiding, en kan nie meer verlossing vir die mens bied nie.
- Sekere konsepte van God, gewoonlik by die klassieke leer of doktrine van God, moet vernietig word.

- Mense ervaar nie God nie. Indien hulle Hom ervaar, is dit slegs as afwesig, versteek en stil.

- Daar word gode geskep in mense se gedagtes, maar die gode moet sterf, sodat die ware God ontdek kan word.

- Dit het 'n mistieke betekenis: God moet doodgaan in dié wêreld, sodat Hy in ons gebore kan word.

- Die taal wat ons gebruik, sal altyd ontoereikend en nie genoeg wees om oor God te praat nie. Dit sal nooit perfek wees nie. (bl. 194)

\section{Teopoëtika (radikale Godstaal) se ontwikkeling en konsepte}

Reyes en Keefe-Perry (2015) definieer teopoëtika soos volg:

Theopoetics often focuses on the intersection of theology with one or more of the following, often with several lenses being in place at once: aesthetics, literary criticism, embodiment, philosophies of the imagination, process-relational thought, hermeneutics, and post- and de-colonizing pedagogy. (bl. 3)

Teopoëtika is opgebou en ontwikkel uit ' $n$ aantal konsepte wat in hierdie afdeling net kortliks genoem sal word. Soos vroeër vermeld in die artikel is teopoëtika al in ander lande en tale ontwikkel binne die teologie, filosofie en selfs die letterkunde, hoewel dit in Afrikaans nog nie allerweë aandag geniet het nie. Hierdie konsepte is nie die enigste terme wat die ontwikkeling van teopoëtika aandui nie. Dit word wel weergegee om die ontwikkeling en omskrywing daarvan uit te wys. Teopoëtika is die 'moeilik-om-tedefinieer-essensie' (Taylor 2008:39).

\section{Poëtiese analise}

Die eerste term waaruit teopoëtika opgebou is of bestaan, is poëtiese analise. Poëtiese analise is 'n estetiese en kreatiewe voorstelling van kwalitatiewe navorsing. Poëtiese analise kan gedefinieer word as 'n metode wat data op 'n kreatiewe manier benader en ekspressief en kunstig voorstel. Poëtiese analise kan nie sonder die metafoor bestaan nie.

\section{Metafoor}

Een van die sentrale terme van teopoëtika is by uitstek die metafoor. Metafore is so oud soos die mens self. Wolterstoff (1984:562) wys daarop dat die metafoor 'n filosofiese onderwerp is wat meer as enige ander deur taalfilosofie bespreek word - vanaf Aristoteles se tyd word metafore gebruik, omdat metafore nie vasgevang kan word in 'n bepaalde definisie nie.

'n Metafoor verbind twee sake wat dalk nie eers met mekaar verband hou nie op ongewone wyses deur hulle met mekaar te vereenselwig sodat die verbinding nie gewoon of vanselfsprekend word en uiteindelik wéér omslaan in 'n vaste patroon of 'n definisie nie (Hays 2004; vgl. ook Van der Watt 2000:6). 'Metaphors allow two semantic domains to interact creatively' (Thiselton 1992:236). Metafore kan ook 'n wêreld vir die mens binne sy of haar konteks skep. Mense 
skep metafore na gelang van hulle verhale. Elke persoon beskik oor 'n narratief of storie wat vir daardie individu sin maak en uitdrukking gee aan hulle verhaal.

\section{Narratiewe teologie}

Elke persoon het 'n meesternarratief of storie, en die Bybel se narratief bestaan hoofsaaklik uit mense se verhale. Die Bybel bestaan uit heelwat meer narratief as enige ander genre. Daarom word teopoëtika ook beïnvloed deur die narratiewe teologie. Narratiewe teologie word ook by kere postliberale teologie genoem en is in die laaste helfte van die 20ste eeu ontwikkel.

Narratiewe teologie ondersteun die argument dat wanneer die Bybel gebruik word, daar meer klem gelê moet word op die narratiewe representasie van geloof, eerder as om vas te val in 'n stel reëls of dogma. Dit is die wegbeweeg van Sistematiese Teologie, nie deur te sê dat Sistematiese Teologie verkeerd is nie, maar deurdat teopoëtika 'n wegbeweeg toelaat van subjektiewe leerstellings af. Die Bybel vertel vele verhale wat oor eeue heen strek en wat beïnvloed is deur plek, tyd, ruimte en selfs kultuur. Die Bybel bied 'n verskeidenheid van perspektiewe, en stories kry waarde deur dít wat die individu aan hulle toeskryf. Mense se verhale is hoofsaaklik subjektief en daarom word postmoderne filosofie ook gereken as 'n rigting waaruit teopoëtika ontwikkel het.

\section{Postmoderne filosofie}

Postmoderne filosofie is 'n wêreldbeskouing wat gekenmerk word deur skeptisisme en mistiek. Dit meen dat die Christelike geloof meer as een dimensie van uiting het. Alle verklarings van die werklikheid is subjektiewe konstruksies en bevat nie objektiewe waarheid nie. Alle benaderings om die werklikheid te kan beleef is geldig (Nürnberger 2007:12). Rossouw (1993:900) meen in postmoderne terme is dit nie moontlik om 'absolute waarheid' ten opsigte van enige gebeure te bewys nie. Daar is ' $n$ voortdurende proses waarin mense betekenis aan dinge en gebeurtenisse toeskryf.

Postmoderne filosofie kan veral in die Franse filosofie vanaf die 1950's gesien word. Postmoderne filosowe werk vanuit die uitgangspunt dat die 'werklikheid' te kompleks is om by 'alle teorieë' in te pas. Filosowe soos Friedrich Nietzsche en Martin Heidegger word beskryf as postmoderne filosowe.

\section{Sosiale konstruksie en narratief}

Sosiale konstruksie beteken dat elke individu betekenis deur taal konstrueer. Mense is aktief of implisiet besig om hulleself en ander te konstrueer of te rekonstrueer. Taal en denke is nie afsonderlike entiteite nie. Taal vorm die basis van denke (Burr 1995:39-44). Deur taal kan wêrelde geskep word en uiteindelik kan 'n nuwe wêreld gevisualiseer en verbeel word. Verbeelding dra by tot die skep van 'n wêreld.

\section{Verbeelding}

Die term 'verbeelding' bevat heelwat semantiese betekenisse. In Grieks word verbeelding tweeledig gesien as phantasia (fantasie) en eikasia ('n beeld); in Latyn word die woord imaginatio gebruik, in Duits Einbildungskraft en Phantasie en in Engels (en Frans) die woord imagination (Warnock 1978:10).

Verbeelding kan beskryf word as die raakpunt waar die onsigbare God ontmoet kan word. Ongelukkig is daar die negatiewe konnotasie dat verbeelding slegs onwerklik of net 'n illusie is. Hand aan hand met verbeelding speel estetika ook 'n rol. Die mens heg waarde aan dit wat esteties mooi en goed is.

\section{Estetika}

Die mens is wesenlik homo aestheticus en nie in die eerste plek homo faber (die mens wat kan maak) nie (Louw 2015:1).

In other words, we want to bathe in Mozart's music. We want to become a part of the Swiss Alps. We want to receive our spouse into ourselves. We want not merely to behold the Bread of Life; we want to eat it, and in so doing, find ourselves truly known. (Taylor 2008:41).

Estetika is veelkantig en bied ook in besonder ruimte vir individue om self te mag kies en ontdek wat hulle as esteties beleef. Van Erp (2004:46-47) meen dat Baumgarten (1735) estetika beskryf as die kuns om mooi te kan dink. Om 'mooi te kan dink' is taal, verbeelding en estetika nodig. Dit is ook soms in die estetiese waar die 'geheimenis' of die misterie opgesluit lê. Elke individu het al so 'n ervaring gehad. Die beskrywing van 'n skildery wek verskillende emosies en denke en ook mistieke gedagtes by mense.

\section{Mistiek}

Mistiek sluit aan by verbeelding, waar verbeelding weer by taal aansluit. Die belangstelling in spiritualiteit en mistiek is wêreldwyd een van die sterkste nuwe tendense in die godsdienstige diskoers - vir baie jare is mistiek binne die Protestantse gelooftradisie as sleg gesien.

Die wortels van die mistiek lê in die Bybel. Die veronderstelling van die Bybel is dat daar persoonlike kontak tussen God en mens kan wees en dat eensaamheid en onttrekking van ander dinge 'n rol kan speel in die aanloop daartoe (Nicol 2002:46).

Die belang van die tema word dikwels onderstreep deur 'n gewilde aanhaling van die invloedryke Karl Rahner (1981:155) dat die Christendom van die toekoms mistiek sal wees of sal ophou om te bestaan. 'The Christian of the future will be a mystic or he or she will not exist at all.'

Die bogenoemde rigtings stel die ontwikkeling voor van hoe teopoëtika uiteindelik tot stand gekom het. Dit is die rigtings wat dit moontlik maak dat teopoëtiese taal oor God kan bestaan. Teopoëtika kan dan uiteindelik kortliks weergegee word as 'n spesifieke manier van dink, praat, skryf en ervaring weergee, soos Heidegger (1996:41) dit noem, om-in-die-wêreld te-wees (Dasein). 


\section{Poësie en teopoëtika se verhouding}

Teopoëtika wil - soos die Bybel verskeie moontlikhede toon om oor God te praat - 'n stap in 'n rigting neem om aan te dui dat postmoderne Godstaal ook as 'n moontlikheid dien om oor God te praat deur die gebruik van poësie.

Poësie is 'om te maak of skep'. Poësie bied die ruimte om uit te wys dat woorde 'n dubbele lewe het. Woorde het meer as een geleentheid om as't ware 'hulle sê te sê'. Poësie kan beskryf word as die lewensbloed van taal, dit is soos die hart wat bloed deur die liggaam vervoer, omdat dit oor die vermoë beskik om te kan skep. (Dit is óók wat teopoëtika wil doen). Teopoëtiek is Godstaal na die dood van God. Hierdie artikel wil bepaal of dit wel moontlik is om deur die gebruik van poësie oor God te kan praat na die dood van God. Teopoëtika en poësie toon daarom baie raakpunte. Albei wil uitwys dat taal 'n kragtige 'vervoermiddel' is en nie net die oordrag van kennis hoef te wees nie.

Eerstens kan poësie as ongerep beskryf word, omdat dit die taal van taal is (Heidegger [1971] 1996:192; vgl. ook Meylahn 2013:300). As daar verwys word na die taal van taal, beteken dit dat 'n mens taal erf - dit word oorgelewer van geslag tot geslag - en hierdie oorgeërfde taal skep 'n wêreld, deur die proses van 'poiesis'.

Hierdie skeppingsproses kan beskryf word as die nukleus waarvan daar wegbeweeg word. Heidegger is oortuig dat die essensie van taal deur poësie gemanifesteer word: 'In its essence, language is neither expression nor an activity of man' (Heidegger [1971] 1996:197) Dit kan verstaan word dat die mens nie die taal praat nie, maar dat die taal of Dasein (deur) die mens praat.

Heidegger (1971) skryf die volgende hieroor:

Poetry ... is not an aimless imagining of whimsicalities and not a flight of mere notions and fancies into the realm of the unreal. What poetry, as illuminating projection, unfolds of unconcealedness and projects ahead into the design of the figure, is the Open which poetry lets happen, and indeed in such a way that only now, in the midst of beings, the Open brings beings to shine and ring out. (p. 72)

Met Heidegger se bogenoemde stelling in ag geneem, dui sy latere werke (1971:74) aan dat poësie taal se suiwerste vorm is ('poetry is language in its purest form'). Dit is in die poësie waar die mens die heilige kan ontmoet. Meylahn (2015) meen:

In other words, things (texts) have meaning only because they are embedded (find a home/are given a place) within a particular context (my or our world) and it is therefore this context (my world) that gives them place: meaning and identity. (2)

Poësie maak postmetafisiese Godstaal moontlik, omdat dit in die essensie oor die skep van taal handel.

Tweedens wil teopoëtika die moontlikheid daarstel dat voordat die mens God op 'n rasionele, metafisiese, teologiese manier wil beskryf, God gevind kan word in poësie. Saam met die poësie lê ook die mistiek (die dubbele lewe van woorde.)

Gemeenskappe en kulture glo dat hulle uitkyk op die wêreld korrek en waar is. Dit is meestal omdat mense saamgebind word deur eiesinnige metafisiese idees. Teopoëtika wil deur poësie en uitwys dat kreatiewe ervarings van God 'n moontlikheid is en dat taal na die dood van God juis oor God kan praat.

Om 'n sinvolle en voldoende manier te vind om oor God te kan praat, was nog altyd 'n uitdaging. Dit is eers onlangs dat terme soos 'absolute', 'misterie', die 'Ander', die 'ander as Ander of andersheid' (vgl. Stoker 2012:225; vgl. ook Verhoef 2016:345-370) gebruik word om God te beskryf. Dis die wegbeweeg van konkrete sisteme, denke en dogmas en eerder die aanvaarding dat God se misterie veel groter is as wat die mens kan beskryf.

Teopoëtika bied die moontlikheid om oor God te praat, maar om weg te bly van tradisionele teologiese Godstaal of 'n totale wegdraai na ateïsme. Teopoëtika praat oor en met God.

Insgelyks bied poësie en teopoëtika 'n moontlikheid vir postmetafisiese Godstaal. Beide maak spasie (Gelassenheit). Beide bied ook ruimte vir verbeelding en die mistiek. Poësie en teopoëtika wil nie gedefinieer word nie, maar wil saambind. Hulle wil nie soos spykers deur hout gekap word nie, maar wil saambind soos die wind waai. Hulle wil ervarings eg maak en deur die krag van taal weergee, sonder konkrete definisies.

Die vraag wat aansluit by die ruimte wat poësie skep, is of De Villiers se poësie as teopoëtika (theopoetics) beskou kan word. Is daar meer sinvolle maniere om oor God te praat en te dink in die postmoderne, postmetafisiese wêreld?

\section{Teopoëtika: 'n Radikale Godstaal}

Teopoëtika is radikale Godstaal. Oor die eeue heen was die taal wat vir God gebruik is dikwels moeilik, dubbelsinnig, wetenskaplik en uiteindelik onverstaanbaar. Dekades lank moes apologete God se bestaan verdedig. As God metafisies en wetenskaplik beskryf kon word, sou God nie dood gewees het nie. ' $n$ Radikale Godstaal sien die moontlikheid in dat die mens se soeke na God nie opgehou het nie en probeer om deur die gebruik van taal 'n Godstaal te ontwikkel. 'n Radikale Godstaal verstaan dat God gelyktydig teenwoordig en afwesig of versteek kan wees. Dis die paradoksale beskrywing van God waar God Homself as versteek (hidden) openbaar.

Dis nie 'n hibried of selfs 'n middeweg nie, maar dalk eerder 'n derde weg - in die taal van Kearney (2001, 2010) - om 'n radikale Godstaal te kan ontwikkel. Dis die wegbeweeg van die metafisiese definisies van God en om daardeur eerder die klem te plaas op God se verborgenheid in sy openbaring. 
In teopoëtika word die tekortkominge van fisika, metafisika, filosofie en taal erken. Godstaal is ook afhanklik van teks en konteks (vgl. Meylahn 2013:301), maar dit bied ruimte vir God om herbeskryf en oorbeskryf te kan word. Dit is nie afhanklik van reëls en definisies nie. Dit is ' $n$ openbaring in die afwesige.

'n Radikale Godstaal is die vernuwing van taal en verbeelding en 'n soeke na die mistieke. Alves (1990) verwoord opsommenderwys sy verstaan van teopoëtika:

It is not theology. Theology wants to be science, a discourse without interstices ... It wants to have its birds in cages ... Theopoetics instead, empty cages, words which are uttered out of and before the void ... (p. 99)

Radikale Godstaal maak figuurlik voëlhokke leeg, sodat God verwoord kan word in 'n postmoderne wêreld. Teopoëtika bied die middeweg om sinvol oor God te kan praat wanneer die metafisika tekortskiet. Kearney (2010) beskryf dit treffend: 'God neither is nor is not, but may be.' Keller (2013:183) beskryf dit soos volg ter aansluiting by God wat nie is nie, maar nog kan word: 'Theopoetics begins not where theology ends, but where it becomes. That is, where theology negates itself becomingly.'

Wanneer Teopoëtika as 'n radikale Godstaal beskryf word, kan dit God se verborgenheid bekendstel en die heilige of die Ander na vore bring. Teopoëtika lig die sluier, sodat die Ander, die andersheid, die misterie, die 'gans andere', beleef kan word.

Die woord surpass (oortref) kan dalk beter verwoord word deur eerder te sê dat poëtika, wat alle taal is, die sluier lig en dat die Ander en andersheid ervaar en beleef kan word. 'n Radikale Godstaal wil meer kuns na vore bring voordat dit die wetenskap voorkeur gee.

Daar kan steeds vandag in taal oor God gepraat word, solank in ag geneem word dat God se teenwoordigheid gelyktydig 'n teenwoordigheid, maar ook 'n versteektheid is. God maak Homself bekend deur Homself as versteek voor te stel.

\section{'n Teopoëtiese lens}

Binne die beperktheid van hierdie artikel sal die gekose lens ${ }^{1}$ wat gebruik word om 'n gedig teopoëties te kan lees, kortliks weergegee word. Meylahn (2012b) bied 'n metode aan wat eintlik ontwikkel is vir die ekklesiologie, maar wat ook toegepas en beskou kan word as 'n teopoëtiese lens. Die vyf bewegings staan bekend as luister, interpreteer, onderskei, poëtika en omarming. Die bewegings vind siklies plaas, om die beweging wat aanhou aan te dui. Die luisterproses word vir die doel van hierdie artikel as die 'leesproses' beskryf. Dit is wanneer die gedig gelees word en die eerste gedagtes wat na vore kom, aangeteken word. Dit is ook om die onvertelde diskoerse oop te breek. In die interpretasieproses word die gedig ontleed en verduidelik. In die derde beweging, wat as die onderskeidingsproses bekend staan, word daar gevra: Kan die gedig as teopoëtika beskou word of nie? Dit beweeg dan siklies na onderskeiding en poëtika wat as die vierde beweging beskryf kan word. Die vyfde beweging is die omarmingsproses en in die proses word gevra hoe 'n gekose gedig teopoëties kan bydra tot die liturgie.

\section{I.L. De Villiers se gedigte as teopoëtika (radikale Godstaal)}

In hierdie artikel sal twee gedigte uit De Villiers se oeuvre aangebied word en dan deur 'n teopoëtiese proses, soos bo bespreek, geneem word. Die teopoëtiese proses wys uit hoe 'n moontlike radikale Godstaal na die dood van God moontlik is.

Die een gedig word as teopoëtika (radikale Godstaal) beskou, terwyl die ander gedig nie as teopoëtika (radikale Godstaal) beskou word nie. Radikale Godstaal (teopoëtika) wys die moontlikhede uit om 'anders' oor God te kan praat. Vir die doel van die artikel se omvattendheid word die verskille uitgewys tussen 'n gedig (uit De Villiers [1972] se oeuvre) wat as teopoëtika beskou kan word en 'n gedig wat nie as teopoëtika beskou word nie. Die skrywer is daarvan bewus dat die bespreking ingeperk is, weens die toelaatbare lengte van die artikel.

Beide gedigte is vanuit De Villiers se eerste bundel Leitourgos, wat in 1972 verskyn het.

\section{Eerste voorbeeld}

\section{'Balansstaat'}

'O', Heer, ek dank $\mathrm{U}$ vir $\mathrm{U}$ groot geduld
met my. Ek is so in die skuld
by $\mathrm{U}$, my bankstaat bly in rooi getik.
Nulle kom voor die komma by - ek sluk
soms swaar daaraan. Ek bied
so min en vra al meer krediet
en kry dit (God weet hoe!).
Ek is soms bang U roep
my in om alles te betaal
en haal my uit $\mathrm{U}$ waagskaal
uit as 'n te groot risiko:
'n Twyfelaar wat glo.

Die gedig sal met gebruik van Meylahn (2012a) se metode gelees word om uiteindelik te kan bepaal of De Villiers se gedig 'Balansstaat' as teopoëtika beskou kan word.

\section{Luister}

Die fokuspunt van De Villiers se eerste bundel, Leitourgos (1972), is waarskynlik die gedig 'Balansstaat': 'n verlore mens, 'n reddende God en "n Twyfelaar wat glo'. Dit maak hierdie gedigte radikaal anders as die Afrikaanse poësie van dieselfde tyd in daardie jaartal. Die grondslag daarvan is juis 
ook die hoofsaak waarmee die gereformeerde teologie besig is, naamlik die religieuse verhouding van die mens tot God.

Met die eerste lees van 'Balansstaat' kan die gedig beskryf word as 'n laaggedig. Dit beteken dat daar meer as een betekenis aan die gedig toegeken kan word. Dit kan ook as gebed dien, veral met die tussenwerpsel ' $\mathrm{O}$ ' aan die begin van die gedig. Die spreker begin met 'n apostroof ' $\mathrm{O}$ ' om God aan te roep.

\section{Interpretasie}

Die leser word na die bankwese geneem en die spreker vertel van hoe hy in die skuld is. Hierdie spreker se balansstaat klop nie. Dit is so erg dat die bankstaat in rooi getik word. Die metafoor van die bankstaat in rooi dui iets van die erns van die spreker aan. Die spreker verduidelik dat daar nulle voor die komma bykom en dat hy swaar daaraan sluk. Die spreker vra ook al hoe meer krediet, terwyl hy so min het om te bied. Keer op keer vergewe God hom, en deur die parentese of inlassing gee die spreker uitdrukking aan sy emosie: 'God weet hoe!'

Die woord 'waagskaal' in plaas van 'weegskaal' word gebruik. Die spreker gebruik digterlike vryheid om die woord so te gebruik. Deur die gebruik van die woord meen die spreker dat God met hom bemoeienis maak. God waag, maar weeg hom nie. Dit kan ook sinspeel op Daniël 5:27, waar koning Belsasar deur God geweeg, maar te lig bevind is. Die woord 'waagskaal' sluit ook aan by die titel van die gedig, naamlik 'Balansstaat'.

Teen die einde gee die spreker sy eie geloof weer: "n Twyfelaar wat glo'. Dit is 'n intertekstuele verwysing na Markus 9:24: 'Ek glo', roep die seun se pa dadelik uit. 'Help my in my ongeloof'. Die spreker besef dat God die enigste een is wat hom uit sy swak geloof kan help en sluit die gedig so af. Die reël gee ook iets daarvan weer dat die digter besef dat God hom nie sal los nie, al is sy bankstaat in rooi. Müller (2011:161) beskryf in sy boek Om te mag twyfel die volgende oor God:

$[D]$ ie Een wat is en wat was en wat kom; die Een wat om elke hoek en draai in enige gedaante of gebeure kan verskyn, maar wat nooit in ons gedagtes en formulerings vasgevang kan word nie. (bl. 161)

\section{Onderskeiding en poëtika}

In die onderskeidingsfase word die gedig as teopoëtika (radikale Godstaal) beskou, veral deur die vernuftige gebruik van metafore soos 'n balansstaat om 'n verhouding met God te vergelyk. Dit is ook dan dat daar ruimte is om te mag wees, dat selfs ' $n$ twyfelaar in God mag glo. Binne 'n postmoderne verstaan van die wêreld is dit dalk nie meer vandag - radikaal nie, maar in die jaar 1972 sou dit as 'n kettery gesien geword het om in God te twyfel. Die gedig bring ' $n$ beweging en vryheid na vore om oor en met God te mag praat. Marion (2012) is van mening as die mens oor God praat, praat die mens ook met God.

\section{Omarming}

'Balansstaat' kan by verskeie momente in die erediens gebruik word. Dit kan by die Woordverkondiging as inleiding gebruik word, veral as daar oor die sin van die lewe gepreek word, maar die gedig kan ook dien as 'n aanvangswoord. Lydenstyd is 'n besonderse tyd vir hertoewyding en roepingvernuwing (Clasen et al. 2010:297). Dit kan ook ná 'n preek 'n mooi 'toeëieningsmoment' wees. Selfs binne 'n stilte-oomblik in die erediens sou die gedig treffend kon funksioneer.

\section{Tweede voorbeeld}

\section{‘Nagmaal (I)'}

Heer, was daar ook so 'n ligte
bewing in U hande toe U die brood
gebreek het? Evangeliese berigte
is uitgesproke dat U kalm was voor U dood
ondanks die slinkse man van Kerjot
se aanwesigheid; ook Thomas en die ander boel
wat eet en drink en van die plan van God
niks weet nie. Hoe het U gevoel?
Ek sukkel met die silwerdekseltjie en stamp
die staanders glasies effens uit hul plek.
Rooi Muscadel word uitgestort - klein ramp -
en vlek die tafellaken. Skielik sien ek
U die beker gee vir iemand aan U sy,
rustig, soos Een wat weet waar Hy sy kudde lei.

\section{Luister}

Met die eerste lees is die titel bekend. Die Nagmaaltafel met die brood en die wyn is simbool van Jesus se soendood vir mense op aarde. Dit het ' $n$ impak op ons vertikale verhouding met God, sowel as ons horisontale verhoudings met mekaar (Wepener 2010:7). Dié gedig is 'n Shakespeariaanse sonnet. Die Shakespeariaanse sonnet bestaan uit 14 versreëls, met die rymskema abab, cdcd, efef, gg. De Villiers volg hierdie indeling presies.

\section{Interpretasie}

Die spreker vra 'n retoriese vraag aan Jesus in die gedig 'Nagmaal I'. Die spreker gebruik kruisrym binne die eerste strofe: ligte en berigte - brood en dood. Hy meen dat die Evangelies wat ons oor die aardse lewe van Jesus vertel, te kenne dat Jesus kalm was voor sy dood, al was Judas in die prentjie (strofe 2).

Die spreker noem Judas die 'slinkse man van Kerjot'. 'Judas Iskariot' is die Hebreeus vir 'Juda, die man van Kerjot'. Dit is 'n plek in Moab. Onder die dissipels was hy die een wat die finansies hanteer het. Dit sê iets van Judas se bekwaamheid, want Matteus of Levi, wat 'n tollenaar was, kon dit net so wel 
gedoen het. Dat geld vir Judas belangrik was, is ook uit die tekste afleibaar. In Markus 14:5 kla Judas byvoorbeeld oor die duur salf wat Maria gebruik om Jesus se voete te salf.

Die spreker verwys ook na Thomas, die twyfelaar, en die ander 'boel'. Die woord 'boel' word gebruik om te rym met die woord 'gevoel' later in die gedig. Die gedig is enjambementies geskryf. Dit beteken dat een versreël oorgaan in die volgende versreël sonder enige leestekens. Die spreker skryf dit so om iets van sy emosie in die gedig weer te gee. Iets van daardie bewing in die hande word beskryf.

'Hoe het U gevoel?' Gevoelens is vir die spreker belangrik. Die spreker meng dogma en ervaring om die beste in beide te soek.

Die spreker neem die leser in die derde strofe terug na die Nagmaaltafel toe. By die sonnet word die gevoelens- en gedagtestroom wat deur die drie kwatryne heen geleidelik na 'n hoogtepunt gevoer word, beklemtoon. In die rymende koeplet aan die einde is daar dan 'n wending,'n samevatting van die geheel, wat die kerngedagte oordra. Hy vertel iets van sy menslikheid en wat hy beleef. Met die gebruik van 'n parentese beklemtoon die spreker die 'klein ramp'. Die beeld wat hier gebruik word, is tweeledig van aard: eerstens die fisieke mors van die rooi Muscadel, maar simbolies voel dit vir die spreker of hy die bloed van Jesus mors.

Maar die gedagte verdwyn vinnig by die spreker as hy in die slotstrofe, wat slegs uit 'n koeplet bestaan, simbolies vir Jesus sien. Die woord 'rustig' word in die bevoorregte aanvangsposisie geplaas om Jesus te beskryf: kalm en rustig. En dan die vergelyking: '[S]oos Een wat weet waar Hy sy kudde lei.' Dié slotreël kan beskou word as 'n intertekstuele verwysing na Psalm 23 of die gelykenis van die verlore skaap. Die gebruik van alliterasie 'wat weet waar' beklemtoon die feit dat Jesus ewig is. In die koeplet kry ons dus die verdieping of kerngedagte van die gedig. Dit is Jesus wat sy kudde lei.

\section{Onderskeiding en poëtika}

Teopoëtika? Nee. Poësie? Ja, veral die gebruik van die Shakespeariaanse sonnet. Die gedig word nie as teopoëtika (radikale Godstaal) beskou nie, veral om die rede dat dit vertel van 'n ervaring by die Nagmaalstafel. Dit is nie 'n nuwe manier om oor God te praat nie. Hoewel die gebruik van die Nagmaal 'n heilige ondervinding is, het die gedig nie werklik 'n dieper betekenis van misterie nie en daarom word dit nie as teopoëtika gesien nie.

\section{Omarming}

Die gedig kan wel aangewend word binne die liturgie by die Nagmaal en 'n sinvolle bydrae lewer tot die erediens. Daar lê 'n diep wonder daarin dat God heilig en ook genadig en die teenwoordige teenwoordigheid is.
Daar bestaan dus potensiaal dat De Villiers se werke, die grootste deel van sy poësie, as teopoëtika beskou kan word en dit sinvol kan bydra tot die gereformeerde liturgie. Die navorsing wat vir hierdie artikel gedoen is, wys dat postmoderne Godstaal moontlik is.

\section{De Villiers se ander gedigte}

In De Villiers se oeuvre is daar nog baie ander gedigte wat as teopoëtika beskryf kan word. 'Balansstaat' (1972:32) as een enkele voorbeeld uit De Villiers se vroeë werke kan as teopoëtika beskryf word omdat die spreker die leser in die bankwese plaas en die spreker vertel hoe hy in die skuld (by God) is. Hierdie spreker se balansstaat klop nie. Dit is so erg dat die bankstaat in rooi getik word.

'n Ander voorbeeld uit De Villiers (2008) se laaste bundel is die gedig 'In die begin'.

In die begin was ek 'n gedagte

in die gestringde stergeheue van God.

In die begin was ek 'n gedagte. (bl. 42)

Die gedig beskryf die skeppingsproses op 'n nuwe manier. Die spreker is van mening dat die mens in die 'gestringde stergeheue van God' ingebed is. Dit word dan ook as teopoëtika beskou. Die meerderheid van De Villiers se gedigte besit ' $n$ misterieuse ondertoon. Teopoëtika het egter in sy werke gegroei.

\section{Afsluiting}

God oortref menslike taal en daarom kan 'n ontmoeting tussen die mens en die 'gans andere' deur die gebruik van beeldspraak, simbole en metafore uitgedruk word. Dit is om hierdie rede dat 'n radikale Godstaal in die gereformeerde tradisie moontlik is. God se openbaring vind in beelde plaas. Die Bybel is 'n beeldeboek, 'n boek vol prente. Teopoëtika kyk na die metaforiese wêreld van taal, maar neem dit ook verder as bloot metafore. Teopoëtika skep 'n ruimte wat toelaat dat verskeie momente versterk, vergroot en beleef kan word, veral in die liturgie. Dit kan selfs 'n invloed op die koinonia van 'n gemeente hê. Die liturgie in die gereformeerde tradisie moet uiteindelik op 'n plek kom waar dit as teopoëtika beskou kan word. Teopoëtika bied die moontlikheid van 'n postmoderne Godstaal waarin individue 'n veilige ruimte kan vind. Dit wys die moontlikhede uit om steeds oor God te kan praat in 'n postmetafisiese, postmoderne wêreld.

Mag die gereformeerde tradisie en ook die gebruik van poësie méér klem plaas op 'n teopoëtiese (radikale) Godstaal.

\section{Erkenning}

Die artikel is gebaseer op die PhD proefskrif van ds. N. Smit onder die leiding van prof. Johann Meylahn. 


\section{Mededingende belange}

Die outeurs verklaar dat hulle geen finansiële of persoonlike verbintenis het met enige party wat hulle nadelig kon beïnvloed in die skryf van hierdie artikel nie.

\section{Outeursbydraes}

N.C.S. is die skrywer van die artikel, gebaseer op sy $\mathrm{PhD}$, onder die toesig van sy promotor J-A.M.

\section{Etiese oorwegings}

Hierdie artikel volg alle etiese standaarde vir navorsing.

\section{Bevondsing}

Hierdie artikel is befonds deur die Akademie vir Wetenskap en Kuns.

\section{Data beskikbaarheidverklaring}

Data-deling is nie van toepassing op hierdie artikel nie, aangesien geen nuwe data geskep óf geanaliseer is nie in geanaliseer in hierdie studie is nie.

\section{Vrywaring}

Die sienings en menings wat in hierdie artikel uitgedruk word, is dié van die skrywers en weerspieël nie noodwendig die amptelike beleid of posisie van enige geaffilieerde agentskap van die skrywer nie.

\section{Literatuurverwysings}

Altizer, T. \& Hamilton, W., 1966, Radical theology and the death of God, Bobs-Merril, New York.

Alves, R.A., 1990, The poet, the warrior, the prophet, Trinity, Philadelphia, PA.

Baumgarten, A.G., 1735, Reflections on poetry, University of California Press, Berkeley. Burr, V., 1995, An introduction to social constructionism, Routledge, New York, NY.

Clasen, F., Carstens, C., Bartlett, A. \& Schoeman, F., 2010, Handleiding vir die erediens, Bybelmedia, Wellington.

De Villiers, I.L., 1972, Leitourgos, Tafelberg Uitgewers, Kaapstad.

De Villiers, I.L. 2008, Vervreemdeling, Tafelberg Uitgewers, Kaapstad.

Ferguson, S.B., Wright, D.F. \& Packer, J.I.,1988, New dictionary of theology, InterVarsity Press, Downers Grove.

Frame, J., 1988, 'Death of God theology', in S.B. Ferguson, D.F. Wright \& J.I. Parker (eds.), New dictionary of theology, pp. 188-189, InterVarsity Academic, Downers Grove, IL.

Handboek van die Afrikaanse taal, 2015, 6de uitg., Pearson, Kaapstad.

Hays, R.B., 2004, The moral vision of the New Testament: A contemporary introduction to New Testament ethics, Biddles, London.
Heidegger, M., 1971, Poetry, language, thought, vert. A. Hofstadter, Harper Collins, New York, NY

Heidegger, M., 1977, 'Letter on humanism', in Basic writings, vert. D.F. Krell, pp. 189-242, Routledge, Londen.

Heidegger, M., [1971] 1996, Being and time, State University of New York Press, Albany, NY.

Holland, S., 2007, Theology is a kind of writing: The emergence of theopoetics', Cross Currents 47(1), 317-331.

Hopper, S.R., 1992, 'The literary imagination and the doing of "theology", in R.M. Keiser \& T. Stoneburner (eds.), The way of transfiguration: Religious imagination as theopoiesis, pp. 209-227, Westminster, Louisville.

Kearney, R., 2001, The God who may be. A hermeneutics of religion, Indiana University Press, Bloomington.

Kearney, R., 2010, Anatheism: Returning to God after God, Columbia University Press, New York.

Keefe-Perry, C., 2014, Way to water: A theopoetics primer, Cascade Books, Eugene, OR.

Keller, C., 2013, 'The Pluri-verse', in R. Faber \& J. Feckanthal (reds), Theopoetic Folds: Philosophizing Multifariousness, pp. 179-194, Fordham University Press, New York.

Louw, D.J., 2015, 'Poetic seeing in visual arts and theology. Aesthetics as a spiritual and loving gaze within the human quest for meaning', Koers - Bulletin for Christian and loving gaze within the human quest for meaning', Koers - Bulletin
Scholarship 80(1), 1-13. https://doi.org/10.19108/koers.80.1.2207

Meylahn, J.-A., 2012a, 'Beyond categories, proper names, types and norms toward a fragile openness (Offenbarkeit) of différance, but always from within the text', HTS Teologiese Studies/Theological Studies 68(1), Art. \#1003, 1-9. https://doi. Teologiese Studies/Theological
org/10.4102/hts.v68i1.1003

Meylahn, J.-A., 2012b, Church emerging from the cracks. A church in, but not of the world, Sun Press, Bloemfontein.

Meylahn, J.-A., 2013, 'The limits and possibilities of postmetaphysical God-talk: A conversation between Heidegger, Levinas and Derrida', Studies in Philosophical Theology 52(1), 289-342.

Meylahn, J.-A., 2015, 'After God: Practical theology as public Christology from the margins of the market', HTS Teologiese Studies/Theological Studies 71(3), 1-9. https://doi.org/10.4102/hts.v71i3.2975

Miller, D.L., 2010, 'Theopoetry or theopoetics?', Crosscurrents 60(1), 6-23. https:// doi.org/10.1111/j.1939-3881.2010.00103.x

Müller, J.C., 2011, Om te mag twyfel, Tafelberg, Kaapstad.

Nicol, W., 2002, Gebed van die hart, Lux Verbi, Goodwood.

Nürnberger, K., 2007, The living dead and the living God, Cluster, Pietermaritzburg.

Marion, J-L., 2012, In the self's place. The approach of Saint Augustine, Stanford University Press, Stanford.

Rahner, K., 1981, 'The spirituality of the church of the future', Theological Investigations 20(1), 149-155.

Reyes P.B. \& Keefe-Perry, L.C. 2015, 'Inside the mirror: Five domains of theopoetic critique on theological education, REA Annual Meeting', viewed 3 March 2020, from https://www.religiouseducation.net/papers/rea2015-reyes(2).pdf.

Rossouw, G.J., 1993, 'Theology in a post-modern culture: Ten challenges', Hervormde Teologiese Studies 49(4), 894-907. https://doi.org/10.4102/hts.v49i4.2528

Stoker, W., 2012, 'Culture and transcendence: A typology', in W. Stoker \& W.L. Van der Merwe (reds.), Culture and transcendence, studies in philosophical theology pp. 225-240, Peeters, Leuven.

Taylor, D., 2008, 'A holy longing', Christianity Today 52(10), 38-41.

Thiselton, A.C., 1992, New horizons in hermeneutics, Zondervan Publishing House, Grand Rapids, MI.

Van Erp, S., 2004, 'The art of theology', DTh proefskrif, Universiteit van Tilburg, Nederland.

Verhoef, A., 2016, 'Die einde van transendensie in kontinentale godsdiensfilosofie?', Litnet Akademies 13(1), 347-370.

Warnock, M., 1978, Imagination, University of California Press, Berkeley, CA.

Wepener, C., 2010, Aan tafel met Jesus, Bybel-Media, Wellington.

Wolterstorff, N., 1984, Reason within the bounds of religion, Eerdmans, Grand Rapids. 